\title{
A psychosocial typology of the unemployed in South Africa
}

\author{
Leoni van der Vaart ${ }^{1,2}$, Hans De Witte ${ }^{1,2}$, \\ Anja Van den Broeck ${ }^{1,2}$ \\ and Sebastiaan Rothmann'
}

\begin{abstract}
The aim of this study was to investigate whether there were different types of unemployed people in South Africa. A psychosocial typology, developed in Europe, identified five types of unemployed people based on their attitudes, behaviour, and experiences. To determine whether the same types could be found in South Africa, we studied a convenience sample of 38I unemployed individuals residing in the Potchefstroom area in the North West province in South Africa. Latent class analysis indicated that only four types of unemployed could be identified in this study: optimists, the desperate, the discouraged, and the adapted. Significant associations were found among these types and background characteristics, mostly in line with previous research. The results may be utilised to design interventions tailored to the different types of unemployed people.
\end{abstract}

\section{Keywords}

Attitudes, behaviour, experiences, latent class analysis, typology, unemployment

Rather than being 'homogeneous', the unemployed seem to consist of individuals with an infinite number of unique combinations of characteristics and experiences (Knopf, 2013). This observation gives rise to the idea that different types of unemployed may exist. A typology is the classification of a relatively homogeneous group into abstract categories called subtypes (Jahiel \& Babor, 2011). Practically, such a typology will enable both policy-makers and practitioners to design and implement policies and interventions tailored to the needs of the unemployed (Houssemand, Pignault, \& Meyers, 2014).

De Witte (1992) developed a psychosocial typology based on self-evaluated affective experiences, attitudes towards work, and search behaviour of long-term unemployed people in Belgium. First, De Witte's typology captures unemployed individuals' (negative) experiences based on the

\footnotetext{
'North-West University, South Africa

${ }^{2}$ Katholieke Universiteit Leuven, Belgium

Corresponding author:

Leoni van der Vaart, North-West University, P.O. I I74, Vanderbijlpark 1900, Gauteng, South Africa.

Email: leoni.vandervaart@nwu.ac.za
} 
deprivation of five latent needs. Jahoda (1982) postulates that employment provides both latent and manifest benefits. Manifest benefits refer to the monetary rewards obtained from employment, whereas latent benefits derive from the satisfaction of five psychological needs: social contact, social status, shared purpose, time structure, and regular activity. Deprivation of the latent and manifest benefits results in a decline in psychological well-being (Jahoda, 1982). However, some unemployed also seem to have positive experiences (Herbert, Drebing, Mueller, \& Van Ormer, 2006). Therefore, this study included an additional dimension, namely positive experiences.

Second, unemployed individuals' attitudes towards employment are reflected in their commitment to employment (De Witte, Rothmann, \& Jackson, 2012), also referred to as work involvement or work-role centrality (McKee-Ryan, Song, Wanberg, \& Kinicki, 2005). Commitment to employment is defined as 'the extent to which a person wants to be engaged in paid work' (Warr, Cook, \& Wall, 1979, p. 130) and reflects the degree to which work may take a central role in one's life (McKee-Ryan et al., 2005). Finally, job search behaviour is operationalised as the frequency with which individuals have engaged in a particular job search activity within a specific time frame (Wanberg, 2012).

Theoretically, experiences, commitment, and job search behaviour are interdependent. For example, job search behaviour is a form of problem-focused coping (McKee-Ryan et al., 2005) with positive outcomes such as an increase in the number of job offers received (Kanfer, Wanberg, \& Kantrowitz, 2001) and increased positive experiences (McKee-Ryan et al., 2005). In addition, cognitive dissonance theory (CDT; Festinger, 1957) suggests that if there is a discrepancy between the importance one attaches to work and one's job search behaviour, one will either alter one's search behaviour or change the value one attaches to work to maintain consensus and reduce negative experiences (Griep, Baillien, Vleugels, Rothmann, \& De Witte, 2013). Long-term unemployment may, thus, decrease the unemployed's active searching behaviour and employment commitment as part of the psychological withdrawal process to cope with negative experiences (De Witte, 1993; De Witte \& Hooge, 1995). Only person-centred research allows for the investigation of the interdependency of variables within individuals (Howard, Gagné, Morin, \& Van den Broeck, 2016) and the identification of types of individuals based on this interdependency.

De Witte (1992) distinguished five different psychosocial types of unemployed people in Belgium (see Table 1).

Despite the country's high unemployment rate, no research has been published to date on types of unemployed people in South Africa (SA). The closest one can get to understanding differences in the unemployed in the South African context involves the grouping of individuals based on their job search behaviour (see Kingdon \& Knight, 2006). Although job search behaviour is relevant, it is unlikely to be sufficient to cluster unemployed individuals. Around the world, other scholars have defined meaningful types based on how they deal with being less involved in society (i.e.,

Table I. Types of unemployed people in Belgium $(N=309)$.

\begin{tabular}{lllll}
\hline Type & $\begin{array}{l}\text { Frequency } \\
(\%)\end{array}$ & $\begin{array}{l}\text { Employment } \\
\text { commitment }\end{array}$ & $\begin{array}{l}\text { Job search } \\
\text { behaviour }\end{array}$ & $\begin{array}{l}\text { (Negative) } \\
\text { Experiences }\end{array}$ \\
\hline Optimists & 28 & Average & Average & Average \\
Desperate & II & Very high & High & Very high \\
Discouraged & 14 & Very high & Average & High \\
Adapted & 17 & High & Low & Low \\
Withdrawn & 30 & Low & Very low & Low \\
\hline
\end{tabular}


sociological; Hoff \& Van Echtelt, 2008), how they experience unemployment (i.e., psychological; Wanberg \& Marchese, 1994), and how they experience unemployment in relation to their social environment (i.e., psychosocial; De Witte, 1992). However, almost all typologies were identified using cluster analysis. Cluster analysis is criticised for the absence of statistical indices and tests on which the number of clusters retained can be based (Steinley, 2003). Latent class analysis (LCA) - one of the best methods to discern typologies - was applied in only one of these studies (see Hoff \& Van Echtelt, 2008). Moreover, only the typology developed by De Witte (1992) was replicated (De Witte \& Hooge, 1995).

This study aimed to examine the psychosocial typology of unemployed people in SA. As such, it makes three important contributions. First, it contributes to theory by classifying different types of unemployed people. We based our study on De Witte's (1992) typology, as (a) it is superior to others in light of its theoretical underpinnings, (b) it has been validated previously and, hence, may be the best candidate to be generalisable (Howard et al., 2016) to the SA context, and (c) it corresponds to Statistics SA's (StatsSA) expanded definition of unemployment: people 'who did not work', 'want to work and are available to start work', 'have taken active steps to look for work or to start some form of self-employment' (StatsSA, 1998, p. 1), or 'did not take active steps to find work' during the reference period (StatsSA, 2017, p. 21). Negative experiences may result from being without work; the individual's attitude towards employment is reflected in being available for work, and the intensity with which one searches for a job is evaluated in looking for work (Griep et al., 2013). Second, this study contributes to practice by identifying different types of unemployed people, each with its specific intervention implications. Third, the study extends research on typologies from a methodological perspective using LCA.

Given the exploratory nature of person-centred research and previous research done in Belgium, no specific hypotheses were set, but we expected to find different types of unemployed. To gain further understanding of the different types of unemployed people, we analysed them regarding demographic differences. Meaningful interpretation and construct validity of the typology depend on meaningful relations with covariates, such as demographic variables (Howard et al., 2016). The demographic characteristics of the unemployed may make it more likely that they will experience unemployment in a particular way (Strandh, Hammarström, Nilsson, Nordenmark, \& Russel, 2013). Indeed, characteristics such as age, ${ }^{1}$ area, number of dependants, highest educational level, employment history, gender, marital status, and unemployment duration may influence how the unemployed cope with unemployment and may affect their chances of re-employment (McKee-Ryan et al., 2005). Therefore, they have been included in several meta-analyses on unemployment and well-being (e.g., Wanberg, 2012) and have been used to characterise the different types of unemployed in Belgium (De Witte, 1992). For example, De Witte established that the optimists comprised more females, were younger, and were more educated; the duration of their unemployment to date was shorter than the other types. The desperate included more males, were older, and had been unemployed longer; they were poorly educated, with less work experience, and struggled more financially. The discouraged were, on average, older. They were not only unemployed for a shorter time than the desperate but also poorly educated and relatively poor. The adapted were, on average, not only older than all other types but also poorly educated and skilled. This type comprised more married individuals with children and had the highest unemployment duration. The withdrawn type comprised significantly more females than males and had the highest number of unemployed with (younger) children. This study assessed the replicability of previous findings by De Witte. Once again, given the exploratory nature of our work, we expected that demographic variables would differ among the different types, but would not generate specific hypotheses. 


\section{Method}

\section{Participants}

The participants were sampled from three areas (assumed to represent diversity in socio-economic status) in the North West province of SA: Potchefstroom (mainly White $=21.1 \%$ ), Promosa (coloured $=54.5 \%$ ), and Ikageng (African $=24.5 \%$ ). The province's expanded unemployment rate $(41.7 \%)$ is greater than the national average of $36.4 \%$ (StatsSA, 2017). A convenience sample of individuals who were unemployed at the time of the study $(n=381)$ participated in the research. Almost three quarters $(73.5 \%)$ had been unemployed for more than 1 year, thus being long-term unemployed. The sample consisted of both females (46.2\%) and males (53.8\%). The majority of the respondents were Afrikaans-speaking (65.4\%) and between the ages of 17 and 30 years (57.3\%), with the minority $(6.27 \%)$ of respondents being older than 50 years. Almost all participants had obtained a Grade 12 or lower $(90.8 \%)$, leaving very few with a diploma or degree.

\section{Instruments}

A biographical questionnaire was used to determine age, area, dependants, education, employment history, gender, marital status, and unemployment duration.

The Experience of Unemployment Questionnaire (EUQ; De Witte, Hooge, \& Vanbelle, 2010) was utilised for measuring participants' affective experiences, attitudes towards employment, and job search behaviour. Questions tapping into negative and positive affective experiences consisted of eight and five items, respectively. Example items included participants rating their experiences (e.g., 'I feel lonelier since losing my job' or 'I have made more friends since I have become unemployed') on a frequency scale ranging from 1 (often) to 3 (never). The importance of work was measured by seven items based on the Employment Commitment Scale of Warr et al. (1979). Participants had to indicate to what extent they agreed with a range of statements (e.g., 'I find it important to have work') on a scale ranging from 1 (agree) to 3 (disagree). Job search behaviour was measured by asking how many times participants had performed any of the five different behaviours (e.g., 'Spontaneously presented yourself to an employer'), reflected on a frequency scale ranging from 0 (never) to 4 (10 times or more). Three additional retrospective questions asked participants to compare their current with their previous affective experiences, the importance of work, and job search behaviour.

\section{Procedure}

A quantitative, non-experimental survey design was used as the strategy of enquiry. Three trained fieldworkers, proficient in English, Afrikaans, and Setswana, administered the questionnaire (which was available in the three languages). Interviews and focus groups were conducted to refine the English version of the EUQ, after which it was translated into Afrikaans and Setswana by professional translators (De Witte et al., 2012). A process of back translation was used, and questionnaires were presented to experts to evaluate face validity. Unemployed people were conveniently selected using door-to-door selection in different areas in town as well as in the informal settlement. Structured interviews, based on the questionnaires, were conducted with most of the participants due to the low levels of education of some participants (De Witte et al., 2012).

\section{Ethical considerations}

The Humanities and Health Research Ethics Committee of the North-West University (NWU-HS-2016-0002) granted ethical approval for the study. A cover letter, attached to the 
questionnaire, specified the purpose of the study and stressed the confidential and voluntary nature of the study.

\section{Data analysis}

Mplus 7.4 (Muthén \& Muthén, 1998-2015) was used for data analysis. Confirmatory factor analysis (CFA) was performed using the mean- and variance-adjusted weighted least squares (WLSMV) estimator. We used the indices to assess fit based on recommendations by Kelloway (2015). Comparative fit index (CFI) and Tucker-Lewis index (TLI) values of .90 are traditionally deemed reasonable (Wang \& Wang, 2012). Root mean square error of approximation (RMSEA) values of .06 indicate a good fit between the model and the data (Hu \& Bentler, 1999), with a non-significant value indicating close fit of the specified model (Wang \& Wang, 2012). A weighted root mean square residual (WRMR) value of 1.00 or lower is considered a good fit (Yu, 2002). The reliabilities of the scales were calculated using the omega reliability coefficient $(\omega)$, which is appropriate for estimating the reliability of variables on an ordinal level (Gadermann, Guhn, \& Zumbo, 2012). LCA was performed on the factor scores of variables identified through CFA (Wang \& Wang, 2012). LCA is a model-based approach to cluster individuals or cases into groups (i.e., latent classes) based on their responses to observed categorical variables (Muthén $\&$ Muthén, 2000). Formal statistical procedures were used to determine the number of classes (Wang \& Wang, 2012). To determine model fit, we used the indices recommended by Tofighi and Enders (2008).

Cross-tabulation was used to determine whether an association existed between the types of unemployed people and the various demographic variables. Pearson's chi-square $\left(\chi^{2}\right)$ test was employed to determine whether these associations between the categorical variables were significant. Cramer's $V$ provided a measure of the strength of the association between the categorical variables (Field, 2013). Cohen's (1988) guidelines were used to determine the magnitude of the practical effect sizes: small (.10), medium (.30), and large (.50).

\section{Results}

\section{CFA for the measuring instruments}

The four latent variables were specified as separate, but related, factors. Based on the fit statistics, the hypothesised model (Model 1) yielded acceptable fit to the data. Model development was performed by deleting one item from the negative experiences scale ('I must save on my personal expenditure') and one item from the importance of work scale ('People do not have to work as such to be constructively occupied') because of inadequate factor loadings (.17 and .10). The revised model (Model 1a) had a good fit (see Table 2).

The reliability coefficients for the respective scales were negative experiences (.91), positive experiences (.80), the importance of work (.90), and job search behaviour (.91).

\section{LCA}

The optimal number of classes was determined by estimating five models with increasing numbers of latent classes and comparing the fit statistics of these models. Table 3 shows the fit indices for the models. The Akaike information criterion (AIC), Bayesian information criterion (BIC), and adjusted Bayesian information criterion (ABIC) values of the model with one latent class were the largest, indicating that this model fitted the data the worst. 
Table 2. Measurement models $(N=380)$.

\begin{tabular}{llllllll}
\hline Model & $\chi^{2}$ & $p$ & $d f$ & TLI & CFI & RMSEA & WRMR \\
\hline Model I & 742.08 & .00 & 344 & .89 & .90 & $.06[.05, .06]$ & 1.35 \\
Model Ia & 596.77 & .00 & 293 & .92 & .92 & $.05[.05, .06]$ & 1.27 \\
\hline
\end{tabular}

$d f$ : degree of freedom; TLI: Tucker-Lewis index; CFI: comparative fit index; RMSEA: root mean square error of approximation; WRMR: weighted root mean square residual.

Table 3. Comparison of LCA models.

\begin{tabular}{lllllll}
\hline Model & AIC & BIC & ABIC & $\begin{array}{l}\text { LMR LR } \\
\text { test } p\end{array}$ & $\begin{array}{l}\text { ALMR LR } \\
\text { test } p\end{array}$ & $\begin{array}{l}\text { BLRT } \\
p\end{array}$ \\
\hline One-class LCA & 2096.92 & 2128.42 & 2103.03 & $\mathrm{~N} / \mathrm{a}$ & $\mathrm{N} / \mathrm{a}$ & $\mathrm{N} / \mathrm{a}$ \\
Two-class LCA & 1902.49 & 1953.68 & 1912.44 & .01 & .01 & .00 \\
Three-class LCA & 1829.48 & 1900.36 & 1843.25 & .33 & .34 & .00 \\
Four-class LCA & 1806.33 & 1896.90 & 1823.92 & .10 & .11 & .00 \\
Five-class LCA & 1782.32 & 1892.57 & 1803.73 & .20 & .21 & .00 \\
\hline
\end{tabular}

AIC: Akaike information criterion; BIC: Bayesian information criterion; ABIC: adjusted BIC; LMR LR: Lo-Mendell-Rubin likelihood ratio; ALMR: adjusted LMR; BLRT: bootstrap likelihood ratio test; LCA: latent class analysis; N/a: not applicable.

We then explored the model with four classes. The first step was to find the best log-likelihood values for the models. The second step was to conduct a five-class analysis to make sure that the $k-1$ class model (four classes) showed the best log-likelihood value found in Step 1. The VuongLo-Mendell-Rubin likelihood ratio (LR) test for four versus five classes had a log-likelihood value of -880.17 (two times the log-likelihood difference $=34.02$, difference in the number of parameters $=5$, mean $=9.66$, standard deviation $[S D]=36.72, p=.20)$. The Lo-Mendell-Rubin (LMR)adjusted LR test (value $=32.91$ ) was also not statistically significant $(p=.21)$. In the third step, a four-class analysis was done. The parametric bootstrap LR test for three versus four classes was statistically significant $(p=.00)$, rejecting the three-class model in favour of the four-class model (Wang \& Wang, 2012). In the three- and four-class models, both the LMR LR and the adjusted LMR (ALMR) LR tests were not statistically significant ( $p>.05$ ), but the bootstrap likelihood ratio test (BLRT) was $(p=.00)$; that is, the first two tests were not in favour of more than two classes. However, in general, the BLRT performs better than the other two tests (Nylund, Asparouhov, \& Muthén, 2007), which cannot reject the three- or four-class models. The AIC, BIC, and ABIC values were smaller in the four-class model, compared to the three-class model. A review of the four-class model compared to the five-class model revealed that both the LMR LR and the ALMR LR tests were not statistically significant $(p>.05)$, but the BLRT was $(p=.00)$. The BIC value of the five-class model was lower than that of the four-class model, and this difference in BIC values (4.37) indicated positive evidence, but not strong evidence (Raftery, 1995). According to Nylund et al. (2007), the BIC value performs consistently. Consequently, the more parsimonious four-class model was preferred.

We then continued with examining the class classification. The entropy values for the two-class, three-class, and four-class LCA were .71, .68, and .70, respectively, which indicated a good classification (Clark, 2010). Only for the four-class LCA model, the posterior class membership probabilities were all larger than .73 , which was larger than the recommended cut-off value of .70 (Nagin, 2005).

As displayed in Figure 1, Class 1 (optimists) had the second lowest mean levels of both negative and positive experiences, the lowest mean levels of the importance they attached to work, and the 


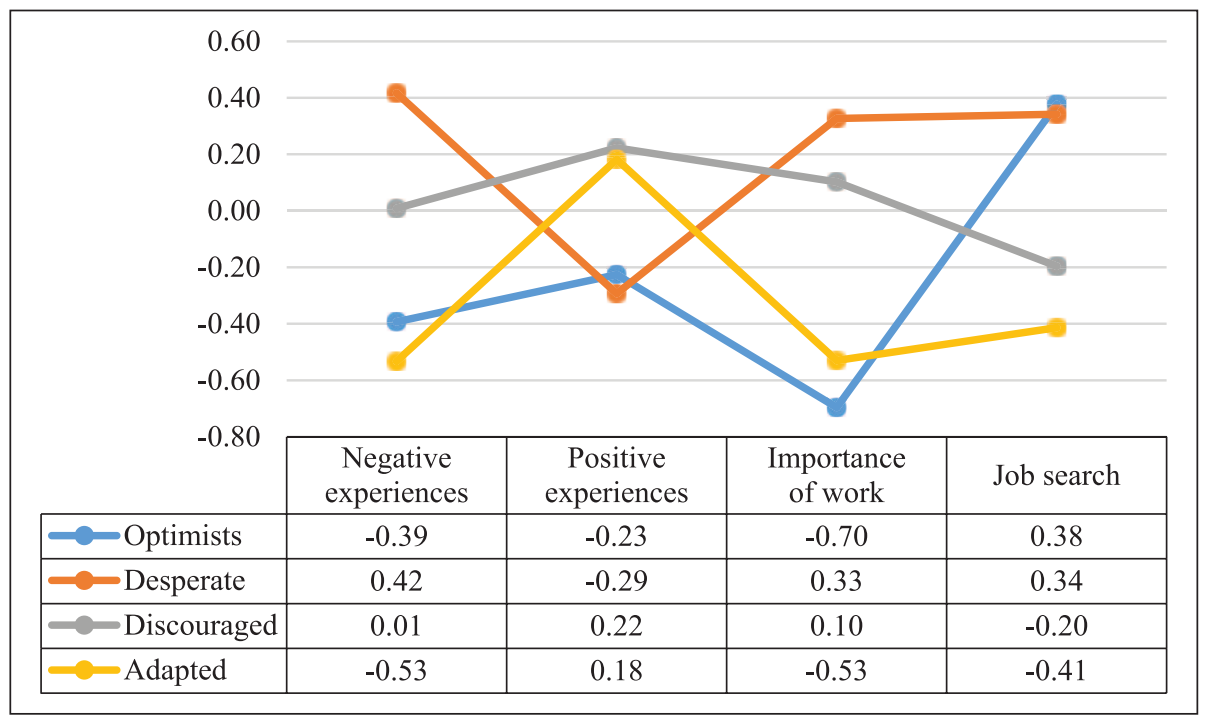

Figure I. The four latent classes.

Table 4. Mean scores for the different types of unemployed people.

\begin{tabular}{lllll}
\hline Type & $\begin{array}{l}\text { Negative } \\
\text { experiences }\end{array}$ & $\begin{array}{l}\text { Positive } \\
\text { experiences }\end{array}$ & $\begin{array}{l}\text { Importance } \\
\text { of work }\end{array}$ & $\begin{array}{l}\text { Application } \\
\text { behaviour }\end{array}$ \\
\hline Desperate & 2.85 & 1.70 & 2.91 & 3.15 \\
Optimists & 2.09 & 1.73 & 2.14 & 3.46 \\
Discouraged & 2.50 & 2.30 & 2.81 & 2.37 \\
Adapted & 1.85 & 2.23 & 2.34 & 1.93 \\
\hline
\end{tabular}

highest mean levels of the intensity with which they applied for jobs; it constituted $11.95 \%$ of the unemployed. Class 2 (desperate) had the highest mean levels of negative experiences, the lowest mean levels of positive experiences, the highest mean levels of the importance they attached to work, and the second highest intensity with which they applied for jobs; it constituted $30.86 \%$ of the unemployed. Class 3 (discouraged) had the second highest mean levels of negative experiences, the highest mean levels of positive experiences, the second highest mean levels of the importance they attached to work, and the second lowest intensity with which they applied for jobs; it constituted $37 \%$ of the unemployed. Class 4 (adapted) had the lowest mean levels of negative experiences, the second highest mean levels of positive experiences, the second lowest mean levels of the importance they attached to work, and the lowest mean levels of the intensity with which they applied for jobs; it constituted $20.19 \%$ of the unemployed.

Table 4 shows the mean scores for each of the dimensions for the respective types.

\section{Cross-tabulations}

The relation between type and age $\left(\chi^{2}\right.$ [degree of freedom $\left.\left.[d f]=6, N=375\right]=13.17, p<.05, V=.13\right)$, type and area $\left(\chi^{2}[d f=6, N=379]=16.87, p<.01, V=.15\right)$, type and level of education $\left(\chi^{2}[d f=6\right.$, $N=373]=24.29, p<.0001, V=.18)$, and type and unemployment duration $\left(\chi^{2}[d f=6, N=370]=12.78\right.$, $p<.0001, V=.13)$ was statistically significant. Three evolution variables were also significantly 
Table 5. Socio-demographic variables by categories of the unemployed.

\begin{tabular}{|c|c|c|c|c|c|}
\hline & $N(\%)$ & $\begin{array}{l}\text { Optimist } \\
\text { (expected } \\
\text { count) }\end{array}$ & $\begin{array}{l}\text { Desperate } \\
\text { (expected } \\
\text { count) }\end{array}$ & $\begin{array}{l}\text { Discouraged } \\
\text { (expected } \\
\text { count) }\end{array}$ & $\begin{array}{l}\text { Adapted } \\
\text { (expected } \\
\text { count) }\end{array}$ \\
\hline \multicolumn{6}{|l|}{ Age (years) } \\
\hline $18-24$ & $119(31.4)$ & $17(12.40)$ & $26(36.80)$ & $46(46.60)$ & $30(23.20)$ \\
\hline $25-49$ & $231(60.9)$ & $22(24.00)$ & $80(71.50)$ & $89(90.60)$ & $40(45.00)$ \\
\hline $50-64$ & $25(6.6)$ & $0(2.60)$ & $10(7.70)$ & $12(9.80)$ & $3(4.90)$ \\
\hline$\chi^{2}(d f)$ & $13.17(6)^{*}$ & & & & \\
\hline Cramer's V & .13 & & & & \\
\hline \multicolumn{6}{|l|}{ Area } \\
\hline Promosa & $206(54.4)$ & $23(21.70)$ & $67(63.10)$ & $82(81.00)$ & $34(40.20)$ \\
\hline Potchefstroom & $80(21.10)$ & $8(8.40)$ & $32(24.50)$ & $20(31.50)$ & $20(15.60)$ \\
\hline lkageng & $93(24.50)$ & $9(9.80)$ & $17(28.50)$ & $47(36.60)$ & $20(18.20)$ \\
\hline$\chi^{2}(d f)$ & $16.87(6)^{* *}$ & & & & \\
\hline Cramer's V & .15 & & & & \\
\hline \multicolumn{6}{|c|}{ Level of education/qualification } \\
\hline Grade II and lower & $243(64.10)$ & $22(26.10)$ & $89(73.60)$ & $97(95.10)$ & $35(48.20)$ \\
\hline Grade 12 & $101(26.60)$ & $14(10.80)$ & $16(30.60)$ & $38(39.50)$ & $33(20.00)$ \\
\hline Tertiary qualification & $29(7.70)$ & $4(3.10)$ & $8(8.80)$ & II (II.40) & $6(5.80)$ \\
\hline$\chi^{2}(d f)$ & $24.19(6)^{* * * *}$ & & & & \\
\hline Cramer's V & .18 & & & & \\
\hline \multicolumn{6}{|l|}{ Unemployment duration } \\
\hline Less than I year & $101(26.60)$ & $13(10.40)$ & $36(31.40)$ & $32(39.90)$ & $20(19.40)$ \\
\hline $2-3$ years & $91(24.00)$ & $12(9.30)$ & $24(28.30)$ & $31(35.90)$ & $24(17.50)$ \\
\hline More than 4 years & $178(47.00)$ & $13(18.30)$ & $55(55.30)$ & $83(70.20)$ & $27(34.20)$ \\
\hline$\chi^{2}(d f)$ & $12.78(6)^{* * *}$ & & & & \\
\hline Cramer's V & .13 & & & & \\
\hline
\end{tabular}

$d$ : degree of freedom.

$* p<.05 ; * * p<.01 ; * * p<.001$.

associated with the typology. The relation between type and unemployment experiences $\left(\chi^{2}[d f=9\right.$, $N=373]=85.26, p<.0001, V=.20)$, type and importance of work $\left(\chi^{2}[d f=9, N=379]=40.81\right.$, $p<.0001, V=.20)$, and type and job search behaviour $\left(\chi^{2}[d f=9, N=370]=33.24, p<.0001, V=.17\right)$ was statistically significant.

The results of the cross-tabulation (Tables 5 and 6) supported the interpretation of the various types. The optimists were younger (24 years or younger), had a higher level of education (Grade 12 and higher), and were short-term unemployed (less than 1 year). Looking at the evolution variables, they felt worse than before, and they considered work as more important than before, but were still investing the same amount of effort in the search process as before. The desperate were, in general, more middle-aged (25-49years), and most of them had relatively lower levels of education (Grade 11 and below). Looking at the evolution variables, they also reported feeling worse than before about not having a job, they considered work as more important than before, and they were making increased efforts to find a job. The discouraged mainly resided in Ikageng, quite a number of them had relatively lower levels of education (Grade 11 and below), and more than half of them had been unemployed for longer than 4 years. Looking at the evolution variables, they also reported feeling worse than before and that they were making less of an effort to search for a job. 
Table 6. Evolution variables by categories of the unemployed.

\begin{tabular}{|c|c|c|c|c|c|}
\hline & $N(\%)$ & $\begin{array}{l}\text { Optimist } \\
\text { (expected } \\
\text { count) }\end{array}$ & $\begin{array}{l}\text { Desperate } \\
\text { (expected } \\
\text { count) }\end{array}$ & $\begin{array}{l}\text { Discouraged } \\
\text { (expected } \\
\text { count) }\end{array}$ & $\begin{array}{l}\text { Adapted } \\
\text { (expected } \\
\text { count) }\end{array}$ \\
\hline \multicolumn{6}{|l|}{ Experiences (feeling) } \\
\hline I feel better than before & $37(9.90)$ & $3(4.00)$ & $3(11.30)$ & $17(14.70)$ & I4 (7.00) \\
\hline I feel worse than before & $277(74.30)$ & $27(29.70)$ & $106(84.70)$ & $118(109.90)$ & $26(52.70)$ \\
\hline I do not feel better or worse & $40(10.70)$ & $7(4.30)$ & $2(12.20)$ & $9(15.90)$ & $22(7.60)$ \\
\hline I have never felt bad & $19(5.10)$ & $3(2.00)$ & $3(5.80)$ & $4(7.50)$ & $9(3.60)$ \\
\hline$\chi^{2}(d f)$ & $85.26(9)^{* * * *}$ & & & & \\
\hline Cramer's V & .28 & & & & \\
\hline \multicolumn{6}{|l|}{ Importance of job (attitude) } \\
\hline Work is more important & $285(79.60)$ & $33(29.50)$ & $95(83.60)$ & II 2 (I I5.40) & $45(56.50)$ \\
\hline Work is less important & $33(9.20)$ & I (3.40) & $7(9.70)$ & $20(13.40)$ & $5(6.50)$ \\
\hline $\begin{array}{l}\text { Work is neither more nor } \\
\text { less important }\end{array}$ & $32(8.90)$ & $3(3.30)$ & $3(9.40)$ & $10(13.00)$ & $16(6.30)$ \\
\hline $\begin{array}{l}\text { Work has never been } \\
\text { important }\end{array}$ & $8(2.20)$ & $0(0.80)$ & $0(2.30)$ & $3(3.20)$ & $5(1.60)$ \\
\hline$\chi^{2}(d f)$ & $40.81(9)^{* * * *}$ & & & & \\
\hline Cramer's V & .20 & & & & \\
\hline \multicolumn{6}{|l|}{ Job search (behaviour) } \\
\hline I look for work more often & $229(61.70)$ & $17(24.10)$ & $87(69.90)$ & $89(91.00)$ & $36(43.90)$ \\
\hline I look for work less often & $58(15.60)$ & $9(6.10)$ & $14(17.70)$ & $27(23.00)$ & $8(11.10)$ \\
\hline $\begin{array}{l}\text { I look for work as often as } \\
\text { before }\end{array}$ & $70(18.90)$ & II (7.40) & $12(21.40)$ & $27(27.80)$ & $20(13.40)$ \\
\hline I have never looked for jobs & $13(3.50)$ & $2(1.40)$ & $0(4.00)$ & $4(5.20)$ & $7(2.50)$ \\
\hline$\chi^{2}(d f)$ & $33.24(9)^{* * * *}$ & & & & \\
\hline Cramer's V & .17 & & & & \\
\hline
\end{tabular}

$d f$ degree of freedom.

$* * * p<.001$.

The adapted were also more long-term unemployed ( 2 years and longer), and the majority had a level of education equal to, or below, Grade 12. Looking at the evolution variables, they felt better about not having a job, work had not really become more or less important to them, and they had not adjusted their search behaviour.

\section{Discussion}

The first aim of this study was to determine whether different types of unemployed could be identified in SA based on the experiences, commitment, and job search behaviour of the unemployed (De Witte, 1992). The results of LCA indicated four types of unemployed people: optimists, the desperate, the discouraged, and the adapted. The fifth type found in Belgium, the withdrawn, was not found in this study. The Belgian withdrawn reported higher than average household incomes (De Witte, 1992). A comprehensive financial unemployment support system is lacking in SA (Klasen \& Woolard, 2008), increasing financial strain (Nordenmark, Strandh, \& Layte, 2006), and preventing the withdrawal of the unemployed. Future research could study whether the withdrawn can be identified among the unemployed who can rely on pension systems that may lower labour force 
participation in multigenerational households (Abel, 2013). Interestingly, there were almost a third fewer optimists and almost three times as many desperate and discouraged unemployed people in this SA sample compared to the Belgian sample. The financial hardship experienced in SA may result in more desperate seekers in SA (Vleugels, Rothmann, Griep, \& De Witte, 2013). The high unemployment rate also means that the supply exceeds the demand, leading to fewer optimists and more discouraged work seekers.

The optimists in this SA sample had a profile typical of the unemployed engaged in problemfocused coping, just as in Belgium. The desperate experienced unemployment as very negative, perhaps because they thought work was important, and they were searching quite intensely for work, yet they remained unemployed. This incongruence between what they wanted and had resulted in distress (Paul \& Moser, 2006). Although the discouraged experienced negative feelings because of the discrepancy between their values and behaviour, their positive experiences could indicate that they were investing their time in something else, which might be worthwhile. The adapted reduced the discrepancy between values and behaviour to reduce negative experiences, in line with the CDT.

While the desperate and discouraged attached equal importance to work in Belgium, the desperate in SA attached higher importance to work than the discouraged. In all, the discouraged in SA were more committed and reported positive experiences, which might be explained by their demographics (the relatively lower educated discouraged in SA who resided mainly in Ikageng) as indicated below. For the adapted in Belgium, work was still important, facilitating their psychological coping (De Witte et al., 2010), but this was not the case in SA.

The categorisation of the unemployed was supported by statistically significant, but small, practical associations with some biographical variables, which provided valuable insight into the profiles. Optimists' background characteristics (younger, educated, and short-term unemployed) might give them a better chance of re-employment, explaining their optimism and problem-focused coping. Younger employees got more job offers and found it easier to find (re)employment (Wanberg, Kanfer, Hamann, \& Zang, 2016). Higher qualified individuals were also more 'employable', while those without a secondary-level education were more likely to remain unemployed (StatsSA, 2017). The shorter the duration of unemployment, the more positive their experiences (Paul \& Moser, 2009), while the more commitment they had, the more intensely the unemployed searched, which is characteristic of problem-focused coping (De Witte et al., 2010).

In both countries, the desperate group consisted of middle-aged (25-49 years) individuals; however, the South African group was less educated than the Belgians. Both age and educational level might explain why these individuals were more committed to work, were desperately seeking jobs, and had negative experiences. It is widely accepted that middle-aged individuals suffer more than younger and older unemployed individuals (Warr \& Jackson, 1984). This is because middle-aged individuals often have more family responsibilities, increasing the importance of the manifest benefit of a job and prompting search intensity, whereas younger individuals tend to have more financial support - perhaps from their parents - and older individuals may have fewer financial resources (Jackson \& Warr, 1984). Middle-aged individuals may also be more committed, tied to their well-being, due to the career phase in which they find themselves. Younger unemployed people may not value employment yet (Lahelma, 1989), and older unemployed people may have distanced themselves from work due to imminent retirement (Kanfer, Beier, \& Ackerman, 2013). Younger and older individuals may also have other social roles that they fulfil, satisfying their latent needs (Winefield, Tiggemann, Winefield, \& Goldney, 1993) and buffering their negative experiences.

Lower levels of education and resultant lower objective employability (StatsSA, 2017) equally influenced the experiences of unemployment, making the unemployed more negative and 
increasing the importance attached to work (De Witte, 1993). Not surprisingly, the discouraged resided mainly in Ikageng, a Black community, and had the lowest educational levels, which might be ascribed to the legacy of apartheid. The positive experiences reported by the discouraged might be a reflection of them valuing the opportunity to spend more time with significant others, derived from a collectivistic culture in which interpersonal relationships are important (Hofstede, 2001). The adapted, both in SA and Belgium, were long-term unemployed, with a relatively lower level of education. Unemployment duration and low educational levels led to reduced search intensity - especially when repeatedly rejected by employers (De Witte et al., 2010) - to facilitate psychological coping.

The findings of this study can be used to further develop interventions aimed at facilitating the transition from unemployment to employment or coping with unemployment, regular monitoring of the unemployed, and policy-making. Interventions customised to the different types are needed because some individuals benefit more from particular interventions than others (Liu, Hang, \& Wang, 2014). Notably, the associations between the types and evolution variables, furthermore, indicate that the optimists, the desperate, and the discouraged feel worse than before. The discouraged make less of an effort to search, and the adapted did not, and still do not, search, with economic implications. The increase in commitment among the optimists and the desperate, although positive from an economic perspective, may have negative psychological consequences if they do not achieve their goal of finding employment. Monitoring should focus on preventing the onset or exacerbation of symptoms through early interventions enhancing psychological functioning. Finally, policies should pay more attention to the psychological aspects of being unemployed.

We contributed to theory and research by showing that the typology might be useful in a nonWestern context to make sense of the phenomenon of heterogeneity in the unemployment experience. Future studies can use this psychosocial typology for identifying different types of unemployed elsewhere to provide further evidence for generalisability. Replication studies in person-centred research enable the identification of a set of core profiles that commonly occur in most contexts and those profiles that may arise due to specific circumstances (Solinger, Van Olffen, Roe, \& Hofmans, 2013). Furthermore, future research should use this typology to identify factors predicting class membership, as well as the outcomes associated with different types of unemployed people, to strengthen the construct validity of this typology and to enable its meaningful interpretation, for which our research has provided a foundation. A significant limitation of this study was the use of a non-experimental survey design and the use of self-report measures. The sample was obtained using convenience sampling and is not representative of the unemployed population of SA. Even though the findings were mostly in line with previous research and supported by theory, the design and sampling method call for more research to evaluate the generalisability of our results. Finally, LCA is also criticised for taking a confirmatory, as opposed to an exploratory, approach (Marsh, Lüdtke, Trautwein, \& Morin, 2009), although we tested several different models.

\section{Conclusion}

The results indicated that four types of unemployed could be identified in this study: optimists, the desperate, the discouraged, and the adapted. These types differed in background characteristics, mostly in line with previous research. The study confirmed that people - with different background characteristics - had different reactions to the same life event of unemployment. Therefore, unemployment programmes should consist of different components, addressing the needs of specific groups. 


\section{Funding}

We gratefully acknowledge the support of the Flemish Interuniversity Council - University Development Cooperation (VLIR-UOS) for awarding funding that enabled the research, authorship, and publication of this article.

\section{Note}

1. Age was categorised as 'young' (18-24 years), 'middle-aged' (25-49 years), and 'older' (50 years and above) in line with literature on unemployment and well-being (see Creed \& Watson, 2003; De Witte, Hooge, \& Vanbelle, 2010; Paul \& Moser, 2009; Wanberg, 2012).

\section{References}

Abel, M. (2013). Unintended labour supply effects of cash transfer programmes: Evidence from South Africa's old age pension (Working Paper No. 114). Cape Town, South Africa: SALDRU, University of Cape Town.

Clark, S. L. (2010). Mixture modeling with behavioral data (Doctoral dissertation). Available from ProQuest Dissertations and Theses database. (UMI No. 3405665)

Cohen, J. (1988). Statistical power analysis for the behavioral sciences (2nd ed.). Hillsdale, NJ: Lawrence Erlbaum.

Creed, P. A., \& Watson, T. (2003). Age, gender, psychological well-being, and the impact of losing the latent and manifest benefits of employment in unemployed people. Australian Journal of Psychology, 55, 95-103.

De Witte, H. (1992). Tussen optimisten en teruggetrokken: Een empirisch onderzoek naar het psychosociaal profiel van langdurig werklozen en deelnemers aan de Weer-Werkactie in Vlaanderen [Between optimism and withdrawn: An empirical investigation into the psychosocial profile of the long-term unemployed]. Leuven, Belgium: Hoger Instituut voor de Arbeid, KU Leuven.

De Witte, H. (1993). ('T is geen) leven zonder werk: Een overzicht van recente literatuur over de psychische gevolgen van werkloosheid [(It's no) life without employment: An overview of the psychological consequences of unemployment]. Welzijnsgids, 12, 1-23.

De Witte, H., \& Hooge, J. (1995). Een vergelijking van typologieen van kort- en langduring werklozen: Wetenschappelijke en beleidsmatige implicaties [A comparison of the typology of shortand longterm unemployed: Scientific and policy implications]. In P. Van der Hallen (Ed.), De Arbeidsmarktonderzoekersdag 1995:Verslagboek (Dossier Nr 12) (pp. 127-142). Leuven, Belgium: Steunpunt Werkgelegenheid, Arbeid en Vorming.

De Witte, H., Hooge, J., \& Vanbelle, E. (2010). Do the long-term unemployed adapt to unemployment? Romanian Journal of Applied Psychology, 12, 8-14.

De Witte, H., Rothmann, S., \& Jackson, L. T. B. (2012). The psychological consequences of unemployment in South Africa. South African Journal of Economic and Management Sciences, 15, 235-252.

Festinger, L. (1957). A theory of cognitive dissonance. Stanford, CA: Stanford University Press.

Field, A. (2013). Discovering statistics using IBM SPSS statistics (4th ed.). London, England: SAGE.

Gadermann, A. M., Guhn, M., \& Zumbo, B. D. (2012). Estimating ordinal reliability for Likert-type and ordinal item response data: A conceptual, empirical, and practical guide. Practical Assessment, Research \& Evaluation, 17(3), 1-13.

Griep, Y., Baillien, E., Vleugels, W., Rothmann, S., \& De Witte, H. (2013). Do they adapt or react? A comparison of the adaptation model and the stress reaction model among South African unemployed. Economic and Industrial Democracy, 35, 717-736.

Herbert, M. L., Drebing, C., Mueller, L., \& Van Ormer, A. (2006). Job search decision making among veterans in VA vocational rehabilitation: A behavioral economics perspective. American Journal of Psychiatric Rehabilitation, 9, 191-218.

Hoff, S., \& Van Echtelt, P. (2008). Erbij of erbuiten: Een typologie van werklozen [Inside or outside: A typology of unemployed]. In P. Schnabel, R. Bijl, \& J. De Hart (Eds.), Betrekkelijke betrokkenheid: Studies in sociale cohesie (pp. 263-276). Den Haag, The Netherlands: Sociaal en Cultureel Planbureau. 
Hofstede, G. (2001). Cultures consequences: Comparing values, behaviors, institutions, and organizations across nations (2nd ed.). Thousand Oaks, CA: SAGE.

Houssemand, C., Pignault, A., \& Meyers, R. (2014). A psychosocial typology of newly unemployed people for profiling and counselling. Current Psychology, 33, 301-320.

Howard, J., Gagné, M., Morin, A. J. S., \& Van den Broeck, A. (2016). Motivation profiles at work: A selfdetermination theory approach. Journal of Vocational Behavior, 95, 74-89.

Hu, L., \& Bentler, P. M. (1999). Cut off criteria for fit indexes in covariance structure analysis: Conventional criteria versus new alternatives. Structural Equation Modeling, 6(1), 1-55.

Jackson, P. R., \& Warr, P. B. (1984). Unemployment and ill-health: The moderating role of duration and age. Psychological Medicine, 14, 605-614.

Jahiel, R., \& Babor, T. F. (2011). Toward a typology of homeless families: Conceptual and methodological issues. Retrieved from http://citeseerx.ist.psu.edu/viewdoc/download?doi=10.1.1.512.7063\&rep=rep1\& type $=$ pdf

Jahoda, M. (1982). Employment and unemployment: A social-psychological analysis. Cambridge, UK: Cambridge University Press.

Kanfer, R., Beier, M. E., \& Ackerman, P. L. (2013). Goals and motivation related to work in later adulthood: An organizing framework. European Journal of Work and Organizational Psychology, 22, 253-264.

Kanfer, R., Wanberg, C. R., \& Kantrowitz, T. M. (2001). Job search and employment: A personality-motivational analysis and meta-analytic review. Journal of Applied Psychology, 86, 837-855.

Kelloway, E. K. (2015). Using Mplus for structural equation modeling: A researcher's guide (2nd ed.). London, England: SAGE.

Kingdon, G. G., \& Knight, J. (2006). The measurement of unemployment when unemployment is high. Labour Economics, 13, 291-315.

Klasen, S., \& Woolard, I. (2008). Surviving unemployment without state support: Unemployment and household formation in South Africa. Journal of African Economies, 18(1), 1-51.

Knopf, S. (2013). Typologies of homelessness: Moving beyond a homogeneous perspective. Retrieved from http://www.nhchc.org/wp-content/uploads/2011/09/InFocus_Jan-2013_FINAL_1.16.13.pdf

Lahelma, E. (1989). Unemployment, re-employment and mental well-being: A panel survey of industrial jobseekers in Finland. Scandinavian Journal of Social Medicine, 43(Supplementum), 1-170.

Liu, S., Hang, J. L., \& Wang, M. (2014). Effectiveness of job search interventions: A meta-analytic review. Psychological Bulletin, 140, 1009-1041.

Marsh, H. W., Lüdtke, O., Trautwein, U., \& Morin, A. (2009). Classical latent profile analysis of academic self-concept dimensions: Synergy of person- and variable-centered approaches to theoretical models of self-concept. Structural Equation Modeling, 16, 191-225.

McKee-Ryan, F., Song, Z., Wanberg, C. R., \& Kinicki, A. J. (2005). Psychological and physical well-being during unemployment: A meta-analytic study. Journal of Applied Psychology, 90, 53-76.

Muthén, B., \& Muthén, L. K. (1998-2015). Mplus user's guide (7th ed.). Los Angeles: Author.

Muthén, B., \& Muthén, L. K. (2000). Integrating person-centered and variable-centered analyses: Growth mixture modeling with latent trajectory classes. Alcoholism: Clinical and Experimental Research, 24, $882-891$.

Nagin, D. (2005). Group-based modeling of development. London, England: Harvard University Press.

Nordenmark, M., Strandh, M., \& Layte, R. (2006). The impact of unemployment benefit systems on the mental well-being of the unemployed in Sweden, Ireland and Great Britain. European Societies, 8, 83-110.

Nylund, K. L., Asparouhov, T., \& Muthén, B. O. (2007). Deciding on the number of classes in latent class analysis and growth mixture modeling: A Monte Carlo simulation study. Structural Equation Modeling, $14,535-569$.

Paul, K. I., \& Moser, K. (2006). Incongruence as an explanation for the negative mental health effects of unemployment: Meta-analytic evidence. Journal of Occupational and Organizational Psychology, 79, 595-621.

Paul, K. I., \& Moser, K. (2009). Unemployment impairs mental health: Meta-analyses. Journal of Vocational Behavior, 74, 264-282.

Raftery, A. E. (1995). Bayesian model selection in social research. Sociological Methodology, 25, 111-163. 
Solinger, O. N., Van Olffen, W., Roe, R. A., \& Hofmans, J. (2013). On becoming (un)committed: A taxonomy and test of newcomer onboarding scenarios. Organization Science, 24, 1640-1661.

Statistics South Africa. (1998). Unemployment and employment in South Africa. Retrieved from www.statssa. gov.za/publications/EmployUnemploy/EmployUnemploy1997.pdf

Statistics South Africa. (2017). Quarterly labour force survey: Quarter 1, 2017. Retrieved from www.statssa. gov.za/publications/P0211/P02111stQuarter2017.pdf

Steinley, D. (2003). Local optima in K-means clustering: What you don't know may hurt you. Psychological Methods, 8, 294-304.

Strandh, M., Hammarström, A., Nilsson, K., Nordenmark, M., \& Russel, H. (2013). Unemployment, gender and mental health: The role of the gender regime. Sociology of Health \& Illness, 35, 649-665.

Tofighi, D., \& Enders, C. K. (2008). Identifying the correct number of classes in growth mixture models. In G. R. Hancock \& K. M. Samuelsen (Eds.), Advances in latent variable mixture models (pp. 317-341). Charlotte, NC: Information Age Publishing.

Vleugels, W., Rothmann, S., Griep, Y., \& De Witte, H. (2013). Does financial hardship explain differences between Belgian and South African unemployed regarding experiences of unemployment, employment commitment, and job search behaviour? Psychologica Belgica, 53, 75-95.

Wanberg, C. R. (2012). The individual experience of unemployment. Annual Review of Psychology, 63, 369-396.

Wanberg, C. R., Kanfer, R., Hamann, D. J., \& Zang, Z. (2016). Age and reemployment success after job loss: An integrative model and meta-analysis. Psychological Bulletin, 142, 400-426.

Wanberg, C. R., \& Marchese, M. C. (1994). Heterogeneity in the unemployment experience: A cluster analytic investigation. Journal of Applied Social Psychology, 24, 473-488.

Wang, J., \& Wang, X. (2012). Structural equation modeling. Chichester, UK: Wiley.

Warr, P. B., Cook, J. D., \& Wall, T. D. (1979). Scales for the measurement of work attitudes and aspects of psychological well-being. Journal of Occupational Psychology, 52, 129-148.

Warr, P. B., \& Jackson, P. (1984). Men without jobs: Some correlates of age and length of unemployment. Journal of Occupational Psychology, 57, 77-85.

Winefield, A. H., Tiggemann, M., Winefield, H. R., \& Goldney, R. D. (1993). Growing up with unemployment. London, England: Routledge.

Yu, C. Y. (2002). Evaluating cutoff criteria of model fit indices for latent variable models with binary and continuous outcomes (Doctoral dissertation). University of California. Retrieved from http://www.statmodel.com/download/Yudissertation.pdf 